\title{
FORMULASI PATI JAGUNG (Zea Mays L) DENGAN TEPUNG TAPIOKA TERHADAP SIFAT FISIKOKIMIA BAKSO IKAN GABUS (Ophiocephalus Striatus)
}

\author{
Imaryana $^{(1)}$, Hermiza Mardesci, S.TP., MP ${ }^{(2)}$ dan Retti Ninsix, S.Tp., MP ${ }^{(2)}$ \\ ${ }^{(1)}$ Alumni Teknologi Pangan Faperta UNISI \\ ${ }^{(2)}$ Dosen Teknologi Pangan Faperta UNISI \\ mimzaaci@yahoo.co.id
}

\begin{abstract}
Abstrak
Tujuan penelitian ini adalah untuk mengetahui pengaruh formulasipati jagung dengan tepung tapioka terhadap analisa kimia bakso ikan gabus. Dari hasil penelitian yang telah dilakukan dalam pengaruh penambahan pati jagung dan pati jagung dengan konsentrasi berbeda terhadap kualitas bakso ikan gabus dapat ditarik kesimpulan bahwa hasil analisa kadar air (12,511\%) memenuhi standar SNI 013819-1995 (BSN 1995), sedangkan kadar lemak (12,5\%) dan kadar protein $(6,0 \%)$ masih belum memenuhi SNI 01-3819-1995 (BSN 1995).
\end{abstract}

Kata Kunci : bakso, ikan gabus, pati jagung

\section{PENDAHULUAN}

Jagung merupakan salah satu hasil pertanian yang banyak di tanam di Kabupaten Indragiri Hilir. Produksi jagung di Kabupaten Indragiri Hilir pada tahun (2012) sebanyak 5.062,50 ton dengan luas tanam $2.691 \mathrm{H}$, tahun (2013) sebanyak $3.619,11$ ton dengan luas tanam $1.932 \mathrm{H}$, tahun (2014) sebanyak 2.974,99 ton dengan luas tanam 2.069 H, dan pada tahun (2015) produksi jagung mengalami peningkatan dari beberapa tahun sebelumnya yaitu 5.210,93 ton dengan luas tanam $3.206 \mathrm{H}$ (Dinas Tanaman Hortikultura dan Hasil Pertanian Kabupaten Indragiri Hilir, 2012-2015). Varietas jagung yang ditanam umumnya lokal hibrida dan petani menanam untuk kebutuhan pemasaran, dalam bentuk tongkol kering dan juga dipetik dalam keadaan muda. Jagung dapat dipanen mulai umur 70 hari setelah tanam, sedangkan jagung kering dapat di panen setelah 4 bulan setelah tanam.

Salah satu produk olahan jagung adalah pati jagung. Pati jagung banyak dimanfaatkan dalam pembuatan kue, makanan kering, sebagai bahan pengental dan berbagai macam makanan, namun belum ada pengolahannya sebagai bahan tambahan di dalam penbuatan bakso. Penggunaan pati jagung akan meningkatkan sifat tekstural bahan makanan dan dapat meningkatkan nilai gizi. Pati mempunyai kemampuan untuk mengikat air sehingga akan meningkatkan kekentalan pada produk makanan. Pati jagung potensial mensubstitusi terigu maupun tapioka dari 20-100\% (Maflahah, 2010). Tepung pati berfungsi untuk mengikat adonan serta memberi tekstur kenyal pada bakso sebagai ciri khasnya. Selain tepung pati juga bisa dipakai tepung yang berasal dari serealia seperti tepung terigu 
(Disperindang 1995). Jenis tepung pati yang baik dipakai untuk pembuatan bakso adalah tapioka (Tepung kanji), maizena (Pati jagung), dan tepung sagu (Alamsyah, 2003).

Ikan gabus merupakan ikan yang hidup di air tawar dan termasuk salah satu potensi alam Indragiri Hilir. Selain rasanya yang enak, ikan gabus juga memiliki kandunganyang bermanfaat bagi kesehatan. Bisnis produk ikan gabus yang telah diolah lebih menguntungkan dibandingkan dengan menjual dalam bentuk ikan segar. Ikan gabus memiliki gizi yang tinggi yaitu protein $42 \%$, lemak $1,58 \%$, abu $6,64 \%$ dan air 4,73\%. Ikan gabus juga merupakan salah satu bahan pangan alternatif sumber albumin bagi penderita hipoalbumin (rendah albumin) dan albumin ini sangat baik di konsumsi pada penderita luka khususnya ibu yang baru melahirkan atau operasi, baik pasca operasi maupun luka bakar (Muflikhah, 2003). Mengingat bahwa kandungan albumin ikan gabus yang cukup tinggi dan memiliki manfaat yang cukup baik untuk kesehatan maka pemanfaatannya dapat dikembangkan dalam bentuk food supplement yang kini sangat diminati seluruh lapisan masyarakat.

Bakso adalah produk olahan yang selama ini menggunakan bahan baku utamanya adalah tepung tapioka. Bakso yang mudah ditemukan adalah bakso yang terbuat dari daging sapi. teksturnya kenyal, berwarna abu-abu, aromanya harum dan berbau rempah, serta rasanya gurih. Selain bakso yang terbuat dari daging, ada juga bakso yang terbuat dari surimi. Bakso ini disebut dengan bakso ikan. Bakso ikan hampir sama dengan bakso yang terbuat dari daging. Perbedaannya hanya terletak pada bahan baku, yaitu ikan. Ikan yang digunakan dalam pembuatan bakso bervariasi, tergantung rasa yang diinginkan. Jenis ikan yang bagus adalah ikan yang memiliki duri menyebar dan mudah dikeluarkan durinnya, serta yang memiliki serat yang banyak. Contoh ikan yang baik untuk diolah menjadi bakso adalah ikan tenggiri, ikan tunadan ikan gabus. Sedangkan kekenyalan bakso dapat diatur berdasarkan tepung yang digunakan.

Menurut (Astuti, 2009), pengaruh jenis tepung dan cara pemasakan terhadap mutu bakso dari surimi ikan hasil tangkap sampingan (HTS) dengan formulasi dua macam tepung yaitu tepung tapioka dan tepung sagu dengan perbandingan $10 \%: 0 \%, 7,5 \%: 2,5 \%$, $5 \%: 5 \%, 2,5 \%: 7,5 \%$ dan $0 \%: 10 \%$, serta dilakukan dengan dua cara pemasakan yaitu perebusan atau pengukusan. Bakso D atau bakso ikan dengan formulasi tepung tapioka 2,5\% dan tepung sagu 7,5\% merupakan bakso ikan terbaik untuk bakso yang dimasak dengan cara perebusan dengan nilai karakteristik organoleptik rasa $(6,83)$, tekstur $(7,57)$; dan nilai karakteristik fisik seperti kekuatan gel $(505,5$ g.cm), uji lipat $(4,03)$, uji gigit $(7,23)$, serta memperoleh karakteristik kimia yang sesuai standar mutu bakso ikan (SNI 013819-1995) dengan air (73,90\%), abu $(1,85 \%)$, protein $(9,70 \%)$, lemak $(0,50 \%)$, dan karbohidrat $(14,05 \%)$.

Berdasarkan uraian tersebut penulis tertarik untuk mengetahui pengaruh formulasi pati jagung dengan tepung tapioka dengan beberapa perlakuan terhadap kualitas kimia dan karakteristik bakso ikan gabus ditinjau dari kadar protein, lemak, dan air dengan mengambil judul "Formulasi Pati Jagung (Zea mays L) dengan Tepung Tapioka terhadap Sifat Fisikokimia Bakso Ikan Gabus (Ophiocephalus striatus)". 


\section{Tujuan Penelitian}

Tujuan penelitian ini adalah untuk mengetahui pengaruh formulasi pati jagung dengan tepung tapioka terhadap analisa kimia bakso ikan gabus.

\section{Manfaat Penelitian}

Dengan dilakukannya penelitian ini, diharapkan dapat memperoleh informasi formulasi pati jagung dengan tepung tapioka yang tepat pada pengolahan bakso ikan gabus.

\section{METODOLOGI PENELITIAN}

\section{Bahan}

Bahan yang digunakan pada penelitian ini adalah air,jagung pipilan kering yang diperoleh dari Perkebunan masyarakat di Desa Kuala Sebatu Parit Taman Baru, Kecamatan Batang Tuaka yang kemudian diolah menjadi pati jagung, ikan gabus, tepung tapioka, es, bawang putih, garam, air bersih dan bumbu. Bahan-bahan yang di gunakan untuk analisa, $\mathrm{K}_{2} \mathrm{SO}_{4}, \quad \mathrm{CuSO}_{4-5} \mathrm{H}_{2} \mathrm{O}$, $\mathrm{H}_{2} \mathrm{SO}_{4}, \mathrm{NaOH}, 10 \mathrm{ml}$ akuedest, $425 \mathrm{mg}$ metal red, $500 \mathrm{ml}$ mentilen blue, $100 \mathrm{ml}$ alcohol $96 \%$, pelarut heksand.

\section{Alat}

Alat-alat yang digunakan dalam pengolahan pati jagung adalah mesin penggiling kedelai, baskom, ember, kain penyaring, karung kecil, talam, dan keranjang besar. Sedangkan dalam proses pembuatan bakso alat yang digunakan meliputi pisau, belender, baskom, panci, timbangan, Alat penirisan, Alat pencetak baksodan kompor. Alat yang digunakan untuk uji kadar air (botol timbang, eksikator, oven, penjepit), uji kadar lemak (alat ekstraksi soxhlet, eksikator, kertas saring bebas lemak, dan neraca analitik), uji protein (labu Kjeldahl, desikator, gelas ukur, pemanas listrik, buret, Erlenmeyer).

\section{Metode penelitian}

Metode yang digunakan adalah metode eksperimen yakni mengadakan pengamatan langsung terhadap objek penelitian. Rancangan yang digunakan adalah rancangan acak lengkap (RAL) dengan perlakuan formulasi pati jagung dengan tepung tapioka dari tiga perlakuan.

A : $\quad 7,5 \%$ Pati Jagung, 2,5\% Tepung Tapioka/BB Ikan Tenggiti.

B : $\quad 5 \% \quad$ Pati Jagung, 5\% Tepung Tapioka/BB Ikan Tenggiti.

C : $\quad 2,5 \%$ Pati Jagung, 7,5\% Tepung Tapioka/BB Ikan Tenggiti.

Perlakuan ini di ulang sebanyak 3 kali sehingga di peroleh pula perlakuan 3 x 3 dengan jumlah 9 perlakuan. Data hasil pengamatan di analisa menggunakan analisa keragaman (analysis of variance) pada taraf nyata $5 \%$ bila berbeda nyata maka di uji lanjut dengan beda nyata terkecil (BNT) pada taraf 5\% model rancangan yang digunakan dalam penelitian ini adalah:

$\mathrm{Y}_{\mathrm{i} i}=\mu+\mathrm{P}_{\mathrm{i}}+\mathrm{E}_{\mathrm{i}}$

Keterangan :

$\mathrm{Y}_{\mathrm{i}^{\mathrm{j}}}$ : Hasil pengamatan terhadap perbandingan pati jagung dan tepung tapioca (1-3)

$\mu \quad$ : Nilai rata-rata (1-3)

$\mathrm{P}_{\mathrm{i}}$ : Pengaruh perbandingan pati jagung dan tepung tapioka (13)

$\mathrm{E}_{\mathrm{ij}}$ : Pengaruh sisa pada suatu percobaan yang dapat perlakuan perbandingan pati jagung dan tepung tapioka (13) pada ulangan (1-3)

i : Perlakuan perbandingan pati jagung dan tepung tapioka (1-3) Ulangan (1-3) 


\section{HASIL DAN PEMBAHASAN}

\section{Kadar Air}

Menurut De man (2007) menyatakan kadar air merupakan faktor utama yang mempengaruhi kualitas pangan. Istilah aktivitas air digunakan untuk menjabarkan air yang tidak terikat dalam bahan pangan. Kadar air dan aktivitas air berpengaruh besar terhadasp laju reaksikimia dan laju pertumbuhan mikroba dalam bahan pangan yang pada akhirnya berpengaruh dalam menentukan mutu dan umur simpan produk pangan selama penyimpanan, kadar air dan aktivitas air akan mempengaruhi sifat-sifat fisiko kimia, perubahan-perubahan kimia kerusakan biologis dan perubahan enzimatis terutama pada makanan yang tidak diolah.

Hasil analisis sidik ragam, kadar lemak bakso ikan gabus menunjukkan bahwa formulasi pati jagung dan tepung tapioka berpengaruh nyata pada taraf $5 \%$ terhadap kadar air bakso ikan gabus dimana $F_{\text {Hitung }}(12,28)>F_{\text {Teble }}(5,14)$. Hasil pengamatan terhadap kadar air bakso setelah uji lanjut dapat dilihat pada Tabel 1.

Tabel 1. Rata-rata kadarAir terhadap Bakso Ikan Gabus

\begin{tabular}{|l|l|}
\hline \multicolumn{1}{|c|}{ Formulasi Pati Jagung dengan Tepung Tapioka } & \multicolumn{2}{|c|}{ Kadar Air } \\
\hline $\mathrm{C}=($ Pati Jagung 2,5\% dengan Tepung Tapioka 7,5\%) & $9.9070 \mathrm{a}$ \\
$\mathrm{B}=($ Pati Jagung 5\% dengan Tepung Tapioka 5\%) & $10.766 \mathrm{a} \mathrm{b}$ \\
$\mathrm{A}=($ (7,5\% dengan Tepung Tapioka 2,5\%) & $12.511 \quad \mathrm{c}$ \\
\hline
\end{tabular}

Keterangan : Angka-angka yang diikuti oleh huruf dan pada kolom yang sama berarti berbeda tidak nyata menurut uji duncan taraf $5 \%$.

Tabel 1 menunjukkan rata-rata pengaruh formulasi pati jagung dengan tepung tapioka terhadap kadar air bakso antara $9.9070 \%$ sampai $12.511 \%$. Kadar air tertinggi diperoleh dari perlakuan A (Pati Jagung 7,5\% dengan Tepung Tapioka 2,5\%). Sedangkan kadar air terendah diperoleh pada perlakuan $\mathrm{C}$ (Pati Jagung 2,5\% dengan Tepung Tapioka 7,5\%). Hal ini disebabkan tingginya kadar air perlakuan A karena persentase pati jagung lebih banyak di banding tepung tapioka. Berdasarkan analisa, pati jagung memiliki kadar air yang lebih tinggi sebesar $14.9 \%$ dan tepung tapioka sebesar $11,3 \%$. Dengan demikian semakin tinggi persentase pati jagung yang di tambahkan maka kadar air bakso juga semakin meningkat.

Kandungan amilosa yang berbeda pada tepung memiliki pengaruh terhadap daya serap air, Pati jagung mengandung amilosa sebesar $26 \%$ dan tepung tapioka 17\%. Menurut (Juliano, 1994), tingkat pengembangan dan penyerapan air tergantung pada kandungan amilosa, semakin tinggi kandungan amilosa, kemampuan pati untuk menyerap air dan mengembang menjadi lebih besar karena amilosa mempunyai kemampuan membentuk ikatan hidrogen yang lebih besar daripada amilopektin. Menurut standar mutu bakso ikan dalam SNI 01-38191995 (BSN 1995),kadar air maksimal untuk bakso ikan adalah $80 \%$. Hal ini berarti bahwa baksoikan gabus yang di formulasi pati jagung dan tepung tapioka telah memenuhi standar yang ditetapkan.

\section{Kadar Protein}

Protein merupakan zat makanan yang penting bagi tubuh manusia, karena berfungsi sebagai bahan bakar dalam tubuh dan juga sebagai bahan pembangun dan pengatur 
(Winarno, 2004). Protein terdapat dalam tumbuhan (biji-bijian, serealia, padipadian) dan hewan (susu, keju, daging, unggas). Penetapan kadar protein pada bakso dilakukan dengan metode mikroKjeldahl. Kadar protein yang diperoleh adalah kadar protein kasar karena dihitung berdasarkan pada nitrogen yang terkandung dalam bahan.

Sudarmadji (1999) menyatakan kadar protein merupakan salah satu kelompok bahan nutrient, tidak seperti bahan makronutrien lainya (karbohidrat dan lemak) protein ini berperan lebih penting dalam penbentukan biomolekul dari pada sumber energi. Namun demikian apabila organisme sedang kekurangan energi. Maka protein ini juga dapat dipakai sebagai sumber energi. Keistimewaan lain dari protein adalah strukturnya yang selain mengandung $\mathrm{N}, \mathrm{C}, \quad \mathrm{H}, \quad \mathrm{O}$ kadang mengandung $\mathrm{S}, \mathrm{P}$ dan $\mathrm{Fe}$.

Hasil analisis sidik ragam kadar protein bakso ikan gabus menunjukkan bahwa formulasi pati jagung dan tepung tapioka berpengaruh nyata pada taraf $5 \%$ terhadap bakso ikan gabus dimana $\mathrm{F}_{\text {Hitung }}$ $(8.33)>\mathrm{F}_{\text {Teble }}(5,14)$. Hasil pengamatan terhadap kadar Perotein bakso setelah uji lanjut dapat dilihat pada Tabel 2.

Tabel 2. Rata-Rata Kadar Protein terhadap Bakso Ikan Gabus

\begin{tabular}{|l|l|}
\hline \multicolumn{1}{|c|}{ Formulasi Pati Jagung dengan Tepung Tapioka } & \multicolumn{1}{c|}{ Kadar Protein } \\
\hline $\mathrm{A}=($ Pati Jagung 2,5\% dengan Tepung Tapioka 7,5\%) & $6.0020 \mathrm{a}$ \\
$\mathrm{B}=($ Pati Jagung 7,5\% dengan Tepung Tapioka 2,5\%) & $7.5066 \mathrm{a} \mathrm{b}$ \\
$\mathrm{C}=($ Pati Jagung 5\% dengan Tepung Tapioka 5\%) & $7.9000 \mathrm{a} \mathrm{b} \mathrm{c}$ \\
\hline
\end{tabular}

Keterangan : Angka-angka yang diikuti oleh huruf dan pada kolom yang sama berarti berbeda tidak nyata menurut uji duncan taraf $5 \%$.

Tabel 2 menunjukkan rata-rata pengaruh formulasi pati jagung dengan tepung tapioka terhadap kadar protein bakso antara $6.0020 \%$ sampai $7.9000 \%$. Kadar protein bakso yang tinggi diperoleh pada perlakuan C (Pati Jagung $2,5 \%$ dan tepung tapioka $7,5 \%$ ) dan yang terendah diperoleh pada perlakuan A (Pati Jagung 7,5\% dan tepung tapioka $2,5 \%)$. Kadungan protein pada pati jagung lebih rendah di bandingkan dengan tepung tapioka, adanya protein yang terdenaturasi pada saat proses perebusan. Perebusan pada suhu $100^{\circ} \mathrm{C}$ mengakibatkan protein akan terkoagulasi sehingga air dari dalam daging yang dikeluarkan lebih besar dibandingkan dengan bahan pangan nabati dengan kadar protein lebih rendah. Menurunnya (Sundari, 2015), kadar protein juga dapat dipengaruhi oleh mikrobia. Halini sesuai dengan pernyataan Darmorejo (2008), bahwa penurunan kadar protein dalam suatu bahan pangan dapat dipengaruhi oleh total koloninya, karena protein merupakan salah satu faktor yang dibutuhkan oleh bakteri untuk berkembang biak. Proses filleting pada ikan gabus juga mejadi sala satu faktor berkurangya kadar protein. Adanya protein yang larut dalam air pada daging ikan yang akan dibuat produk gel ikan, mempunyai pengaruh yang merugikan dalam pembentukan gel ikan (ashi) karena menghambat pembentukan gel (Irianto, 1990). Menurut standar mutu bakso ikan dalam SNI 01-3819-1995 (BSN 1995), kadar protein minimal untuk bakso ikan adalah 9\%. Hal ini berarti bahwa bakso ikan gabus belum memenuhi standar yang ditetapkan. 


\section{Kadar Lemak}

Menurut Djaenai (1995) menyatakan kadar lemak adalah merupakan ikantan organik yang terdiri atas unsur-unsur karbon (C), hidrogen $(\mathrm{H})$, dan oksigen $(\mathrm{O})$ yang mempunyai sifat dapat larut dalam zat-zat pelarut tertentu dalam pelarut lemak. Lemak yang memilikmi titik lebur tinggi bersifat padat pada suhu kamar, sedangkan yang mempunyai titik lebur rendah bersifat cair.

Hasil analisis sidik ragam kadar lemak bakso ikan gabus menunjukkan bahwa formulasi pati jagung dan tepung tapioka berpengaruh nyata pada taraf 5\% terhadap bakso ikan gabus dimana $\mathrm{F}_{\text {Hitung }}$ (12.77) $>F_{\text {Teble }}$ (5.14). Hasil pengamatan terhadap kadar lemak bakso setelah uji lanjut dapat dilihat pada Tabel 3.

Tabel 3. Rata-rata Kadar Lemak terhadap Bakso Ikan Gabus

\begin{tabular}{|l|l|}
\hline \multicolumn{1}{|c|}{ Formulasi Pati Jagung dengan Tepung Tapioka } & Kadar Lemak \\
\hline $\mathrm{A}=$ (Pati Jagung 2,5\% dengan Tepung Tapioka 7,5\%) & $1.6848 \mathrm{a}$ \\
$\mathrm{B}=$ (Pati Jagung 5\% dengan Tepung Tapioka 5\%) & $2.7648 \mathrm{~b}$ \\
$\mathrm{C}=$ (Pati Jagung 7,5\% dengan Tepung Tapioka 2,5\%) & $3.0928 \quad \mathrm{~b} \mathrm{c}$ \\
\hline
\end{tabular}

Keterangan : Angka-angka yang diikuti oleh huruf dan pada kolom yang sama berarti berbeda tidak nyata menurut uji duncan taraf $5 \%$.

Tabel 3 menunjukkan rata-rata kadar lemak bakso berkisar antara $1.6484 \%$ sampai $3.0928 \%$. Kadar lemak tertinggi diperoleh dari perlakuan A (Pati Jagung 7,5\% dengan Tepung Tapioka $2,5 \%)$ sedangkan kadar lemak terendah diperoleh pada perlakuan C (Pati Jagung 2,5\% dengan Tepung Tapioka 7,5\%). Tingginya kadar lemak dipengaruhi olehpersentase pati jagung lebih tinggi dibandingkan persentase tepung tapioka sehingga menyebabkan perlakuan A memiliki kadar lemak tinggi karena dari hasil analisa yang dilakukan pati jagung mengandung kadar lemak 0,3\% per 100 g, sedangkan merut Departemen Kesehatan RI (1996) tepung tapioka mengandung lemak $0,1 \%$ per $100 \mathrm{~g}$. Menurut (Suprapti, 2009) tapioka memiliki kandungan lemak yang paling rendah di bandingkan Maizena dan aren yaitu $30 \%$.

Dalam hal ini pati jagung yang di tambahkan persentasenya lebih tinggi dengan kandungan lemak juga lebih tinggi dari pada tepung tapioka dengan demikain kadar lemak yang terkandung pada bakso ikan gabus akan
tinggi.Menurut pendapat Sueparno (2003), bahwa kadar lemak produk olahan akan meningkat seiring dengan penambahan tepung. Menurut standar mutu bakso ikan dalam SNI 01-38191995 (BSN 1995), kadar air maksimal untuk bakso ikan adalah $1,1 \%$. Hal ini berarti bahwa bakso ikan gabus yang di formulasi pati jagung dan tepung tapioka belum memenuhi standar yang ditetapkan.

\section{KESIMPULAN}

Dari hasil penelitian yang telah dilakukan dalam pengaruh penambahan pati jagung dan pati jagung dengan konsentrasi berbeda terhadap kualitas bakso ikan gabus dapat ditarik kesimpulan bahwa hasil analisa kadar air $(12,511 \%)$ memenuhi standar SNI 013819-1995 (BSN 1995), sedangkan kadar lemak $(12,5 \%)$ dan kadar protein $(6,0 \%)$ masi belum memenuhi SNI 013819-1995 (BSN 1995).

\section{Saran}

Berdasarkan hasil penelitian perlu dilakukan penelitian lebih lanjut 
tentang pengaruh perbandingan ikan gabus dan tepung maizena terhadap mutu bakso, dan cara ekstrasi pati jagung yang lebih tepat sehingga dapat mempertahankan komposisi kimia pati jagung sebagai upaya mengembangkan teknologi inovasi tentang pengolahan hasil berbahan baku jagung.

\section{DAFTAR PUSTAKA}

Alam N, Nurhaeni. 2008. Komposisi kimia dan sifat fungsional pati jagung berbagai varietas yang diekstrak dengan pelarut natrium bikarbonat. Jurnal Agroland. 15.2.

Astuti E F. 2009. Pengaruh jenis tepung dan cara pemasakan terhadap mutu bakso dari surimi ikan hasil tangkap sampingan (HTS). [Skripsi]. Bogor : Fakultas perikanan dan ilmu kelautan. Institut pertanian bogor. Program studi teknologi hasil perikanan.

Fajriannor M, Norkismah, Lianor, Shaufi M, Rizal M, hidayat R, Maslina, Rahman F. 2011. Laporan kegiatan praktikum pembuatan bakso ikan. https://fajrirectaespada.wordpr ess.com. Tembilahan Desember 2015.

Hasanah U. 2014. Formulasi campuran tepung tapioka dengan tepung sagu dan peresentase daging sapi dalam pembuatan bakso daging. [Skripsi]. Tembilahan : Fakultasas pertanian. Universit islam indragiri (UNISI). [Belum di Publikasikan].

Hanriyadi 2010. Pembuatan tepung maizena. http://coco hanri yaditilamuta.blogspot.co.id [Tembilahan Desember 2015].

Nurbaya S. 2014. Subtitusi tepung terigu dengan campuran tepung jagung dan tepung ubi jalar dalam pengolahan mie basah. [Skripsi]. Tembilahan : Fakultasas pertanian. Universit islam indragiri (UNISI). [Belum di Publikasikan].

Maflahah I. 2010. Analisis proses pembuatan pati jagung (maizena) berbasis neraca massa. Jurnal Embryo. 7. 1.

Pereira I. 2013. Tepung jagung (Zea mays L.) dan terigu dalam pembuatan roti tawar. http://tauw.blogspot.co.id/2013 106/tepung-jagung-zea-mays-ldan-terigu.html. [Tembilahan Desember 2015].

Pramitaningrum Y. 2011. Pengaruh penggunaan beberapa jenis pati terhadap karakteristik fisikokimia dan organoleptik yoghurt kental. [Skripsi]. Surakarta : Universitas sebelas maret. Fakultas pertanian. Program studi teknologi hasil pertanian.

Trisnaningsih D. 2014. Kadar protein dan betakaroten bakso ikan tuna yang diperkaya jamur merang (Volvariella Volvaceae) dan umbi wortel. [Skripsi]. Surakarta : Fakultas keguruan dan ilmu pendidikan. Universitas Muhammadiyah. Program studi pendidikan biologi.

Wardani W D. 2008. Isolasi dan karakterisasi natrium alginat dari rumput laut sargassum $s p$ untuk pembuatan bakso ikan tenggiri

(scomberomus commerson). [Skripsi]. Surakarta : Fakultas pertanian. Universitas sebelas maret. Program studi teknologi hasil pertanian. 